CLINICAL STUDY

\title{
Serum proteome changes in acromegalic patients following transsphenoidal surgery: novel biomarkers of disease activity
}

\author{
Diana Cruz-Topete ${ }^{1}$, Britt Christensen ${ }^{2}$, Lucila Sackmann-Sala ${ }^{1,3,5}$, Shigeru Okada ${ }^{1,4}$, Jens Otto L Jorgensen ${ }^{2}$ \\ and John J Kopchick ${ }^{1,5,6}$ \\ ${ }^{1}$ Edison Biotechnology Institute, Ohio University, Athens, Ohio 45701, USA, ${ }^{2}$ Department of Medicine and Endocrinology Aarhus University Hospital \\ and Medical Research Laboratories, Clinical Institute, Aarhus University, 8000 Aarhus, Denmark, ${ }^{3}$ Department of Biological Sciences, ${ }^{4}$ Department of \\ Pediatrics, College of Osteopathic Medicine, ${ }^{5}$ Molecular and Cellular Biology Program and ${ }^{6}$ Department of Biomedical Sciences, College of Osteopathic \\ Medicine, Ohio University, Athens, Ohio 45701, USA
}

(Correspondence should be addressed to J J Kopchick at Edison Biotechnology Institute, Ohio University; Email: kopchick@ohio.edu)

\begin{abstract}
Context: Transsphenoidal adenomectomy is the primary treatment for acromegaly. However, assessment of the therapeutical outcome remains problematic since the existing biomarkers of disease activity frequently show discordant results.

Objective: To discover novel serum biomarkers of disease activity in acromegalic patients before and after surgery.

Design: Serum samples of eight newly diagnosed acromegaly patients before and after transsphenoidal surgery were analyzed for proteomic changes by two-dimensional gel electrophoresis. Protein spots displaying statistically significant changes, pre- versus post-surgery, were identified by mass spectrometry (MS), tandem MS (MS/MS), and western blot analysis.

Results: Six protein spots displaying decreased intensities after surgery were identified as transthyretin (two isoforms), haptoglobin $\alpha 2, \beta$-hemoglobin, and apolipoprotein A-1 (two isoforms). One protein spot, identified as complement $\mathrm{C} 4 \mathrm{~B}$ precursor, was increased after the surgery.

Conclusions: Seven serum protein spots were differentially expressed following surgery in acromegalic patients. The identified proteins represent potential novel biomarkers to assess the effectiveness of surgical treatment in acromegalic individuals. Future studies will validate the use of the identified proteins as biomarkers of disease activity after medical treatment of acromegaly.
\end{abstract}

European Journal of Endocrinology 164 157-167

\section{Introduction}

GH is synthesized and released by somatotropic cells in the anterior lobe of the pituitary gland (1). Abnormal GH secretion leads to impairments in growth and metabolic processes (2-4). Acromegaly is an endocrine disorder, usually the consequence of a GH producing pituitary adenoma (1), characterized by elevated serum levels of $\mathrm{GH}$ and insulin-like growth factor 1 (IGF1) (1, 5). If left untreated or poorly controlled, premature mortality ensues caused mainly from cardiovascular diseases (6-8). The primary treatment for acromegaly remains transsphenoidal surgery (9, 10). GH-secreting microadenomas are usually successfully removed by surgery, whereas the outcome is less favorable with larger tumors (11-13). Assessment of the surgical outcome is therefore important, but no ideal biomarker is currently available (14). Moreover, discrepant results of serum GH and IGF1 levels, i.e. elevated GH and normal IGF1 or vice versa, are often observed (14-16). Thus, the absence of totally reliable biochemical markers of acromegaly makes the evaluation of the treatment outcome difficult.

In this study, experiments were performed to identify serum biomarkers associated with acromegaly before and after transsphenoidal adenomectomy. The serum samples were analyzed using a two-dimensional gel electrophoresis (2DE) proteomic approach and western blotting. Seven proteins displayed significant changes after surgery. These proteins represent biomarkers to evaluate the outcomes of surgical treatment of acromegalic patients. Moreover, results similar to ours reveal potential GH-responsive proteins that could be used to develop assays for the detection of $\mathrm{GH}$ in clinical and sporting (doping) scenarios. 


\section{Materials and methods}

\section{Subjects and serum samples (performed at Aarhus University Hospital, Aarhus, Denmark)}

Eight acromegalic patients (three females and five males) were included in this study and were 26-71 years of age (mean age $=51$ years). All patients presented with classic symptoms and signs of acromegaly including the presence of a pituitary adenoma visualized by magnetic resonance imaging. All patients were treated with surgery alone, i.e. none of the patients had received dopamine agonists, somatostatin analogs, or the GH receptor antagonist, pegvisomant, at any time point, and no patient had received radiation therapy. Serum samples were obtained before and 3-6 months after transsphenoidal surgery. The patients were hospitalized the day before and blood was drawn the following morning in the fasting state and during an oral load of glucose $(75 \mathrm{~g})$. After incubation for 30-60 min at room temperature, the samples were centrifuged at $3500 \mathrm{~g}$ for $10 \mathrm{~min}$ at $4{ }^{\circ} \mathrm{C}$. Serum was removed and stored at $-20^{\circ} \mathrm{C}$ for an interval of $1-4$ years.

All subjects gave a written informed consent before participating in the study, which was approved by The Central Denmark Region Committees on Biomedical Research Ethics (200401184) in adherence to the Declaration of Helsinki. The protocol was also approved by the Ohio University Institutional Review Board.

\section{GH, IGF1, and total haptoglobin measure- ments (performed at Aarhus University Hospital)}

Serum GH was measured by a DELFIA assay (PerkinElmer, Türku, Finland) and serum IGF1 levels were determined by an in-house noncompetitive, timeresolved immunofluorometric assay. Both assays have been previously described (17). Total haptoglobin levels were determined by Cobas c-systems (Roche Diagnostics), in short, human haptoglobin was precipitated with a specific antiserum and the turbidity was estimated. The method had a detection range of $0.1-5.7 \mathrm{~g} / \mathrm{l}$ (or $1.0-57 \mathrm{mmol} / \mathrm{l}$ ) and had a reproducibility of $0.7-1.3$ coefficient of variation $\%$.

\section{Sample preparation for proteomic analysis (performed at Ohio University, Athens, OH, USA)}

Serum samples were shipped frozen on dry ice from Aarhus, Denmark to Athens, Ohio. Upon arrival, samples were stored frozen at $-80{ }^{\circ} \mathrm{C}$ for 3 weeks until further analysis. In general, all proteomic procedures were performed as described previously (18-21). Briefly, serum protein concentrations were determined by the Bradford method. No significant difference in total protein concentration was found between the samples obtained pre- and post-surgery $(P>0.05$ in a paired $t$-test). Albumin depletion of the samples was performed using a ProteoPrep Blue Albumin and IgG Depletion kit (Sigma) following the manufacturer's instructions. After depletion, $0.3 \mathrm{mg}$ of each sample was diluted in sample buffer containing $7 \mathrm{M}$ urea, $2 \mathrm{M}$ thiourea, $1 \% \mathrm{w} / \mathrm{v}$ SB 3-10, 3\% w/v CHAPS, $0.25 \% \mathrm{v} / \mathrm{v}$ Bio-Lyte 3/10 ampholytes (Bio-Rad Laboratories, Inc.), and $1.5 \% \mathrm{v} / \mathrm{v}$ protease inhibitor cocktail (Sigma). Disulfide bonds were reduced by adding tributylphosphine. Following reduction, sulfhydryl groups were alkylated with iodoacetamide.

\section{Two-dimensional gel electrophoresis (performed at Ohio University)}

Samples were subjected to 2DE following procedures previously described (18-21). Serum was transferred to individual wells of an isoelectric focusing (IEF) tray (Bio-Rad) with $17 \mathrm{~cm}$ immobilized $\mathrm{pH}$ gradient (IPG) strips ( $\mathrm{pH}$ 3-10 linear, Bio-Rad) and incubated for $2 \mathrm{~h}$ at room temperature. IEF was then performed in a PROTEAN IEF cell (Bio-Rad), where strips were rehydrated at $50 \mathrm{~V}$ for $12 \mathrm{~h}$ after which proteins were separated at $10000 \mathrm{~V}$ for $60000 \mathrm{~V} \times \mathrm{h}$. Once IEF was complete, the IPG strips were removed and transferred to disposable trays containing $2 \mathrm{ml}$ of equilibration buffer (6 M urea; $2 \%$ SDS; 375 mM Tris-HCl, pH 8.8; $20 \%$ glycerol). The samples were equilibrated with subtle shaking for $45 \mathrm{~min}$. Next, $4.5 \mathrm{~cm}$ was cut from each end of the $17 \mathrm{~cm}$ IPG strips. The resulting $8 \mathrm{~cm}$ strips $(\sim \mathrm{pH}$ $5-8$ ) were loaded on a $15 \%$ polyacrylamide gel for SDSPAGE. Proteins were separated in a Mini-PROTEAN 3 cell $($ Bio-Rad) at $270 \mathrm{~V} \times$ h. Following electrophoresis, the gels were stained using SYPRO Orange (Invitrogen). Images of stained gels were obtained using a PharosFX Plus Molecular Imager (Bio-Rad) with an excitation wavelength of $488 \mathrm{~nm}$ and emission detected at $605 \mathrm{~nm}$. Protein spot intensities and matching were performed using the image analysis software PDQuest Advanced v. 8.0 (Bio-Rad). Spot intensities were normalized to total image density in each gel, which depended on the total protein content of each sample. Protein spots that were differentially expressed between the groups $(P<0.05)$ were excised from the gels and sent to ProteaBiosciences, Inc. (Morgantown, WV, USA) for identification by mass spectrometry (MS) and tandem MS (MS/MS) as described below.

\section{MS analysis (performed at ProteaBiosciences, Inc.)}

Protein spots displaying significant $(P<0.05)$ intensity changes pre- and post-treatment were identified by MS and MS/MS using matrix-assisted laser desorption/ionization-time of flight (MALDI-TOF) and MALDI-TOF-TOF. Acrylamide gel plugs containing individual spots were dehydrated and then rehydrated 
with acetonitrile and $50 \mathrm{mM}$ ammonium bicarbonate respectively. Proteins were then reduced with $250 \mathrm{mM}$ dithiothreitol for $60 \mathrm{~min}$ at $55^{\circ} \mathrm{C}$, followed by alkylation with $650 \mathrm{mM}$ iodoacetamide for $60 \mathrm{~min}$ at room temperature in the dark. Digestion was performed with $500 \mathrm{ng}$ trypsin in $50 \mathrm{mM}$ ammonium bicarbonate buffer overnight. Extraction of peptides was performed using 5\% formic acid in 50\% acetonitrile (dehydration), followed by rehydration with $50 \mathrm{mM}$ ammonium bicarbonate. The procedure was performed three times per sample. The recovered peptides were then lyophilized, reconstituted in $10 \mathrm{mM}$ acetic acid, and re-lyophilized to yield a purified protein digest extract. For MS and MS/MS analyses, the protein digest solution was loaded onto a $\mathrm{C}_{18}$ ProteaTip by aspirating and expelling the sample 5-10 times within the sample vial. The bound sample was washed twice with $0.1 \%$ TFA/2\% acetonitrile solution by aspirating and expelling $20 \mu \mathrm{l}$ of the wash solution 5-10 times. The sample was spotted directly onto an MALDI target that was prespotted with $0.6 \mu \mathrm{l}$ MALDI matrix (CHCA) using $1 \mu \mathrm{l}$ of an elution solution ( $0.1 \%$ TFA/90\% acetonitrile). Mass spectra were acquired on an ABI 4800 MALDI TOF/TOF analyzer. MS spectra were acquired in Reflector Positive Ion mode. Peptide masses were acquired for the range $850-4000 \mathrm{kDa}$. MS spectra were summed from 400 laser shots. Internal calibration was performed using a minimum of three trypsin autolysis peaks. For MS/MS, spectra were acquired until at least four peaks in the MS/MS spectra achieved a signal-to-noise $(\mathrm{S} / \mathrm{N})$ ratio equal to 70 .

\section{Database correlation analysis search par- ameters (performed at ProteaBiosciences, Inc.)}

Protein identification from MS and MS/MS data used the following criteria: program for MS/MS data processing: ProteinPilot 3.0; search engine: Mascot (Matrix Science Inc., Boston, MA, USA); sample type: gel samples; digestion enzyme: trypsin; species: human; database: NCBInr; search engine: type of search: combined MS and MS/MS; mass values: monoisotopic; protein mass: unrestricted; peptide mass tolerance: 土0.3-1 kDa; maximum missed cleavages: 1; variable modifications: carbamidomethyl (C); exclusion mass list: 1151.8, 1358.9, 1795.1, 2211.4, 2225.4, 2283.

\section{Manual protein database searching with MS and MS/MS-generated peak lists (performed at Ohio University)}

Protein identities were further verified by using the MS and MS/MS data obtained and the online software named Mascot. These procedures have been described previously (18-21). Search parameters included the following: MS: database: NCBInr; taxonomy: Homo sapiens; enzyme: trypsin; missed cleavages allowed: 1; fixed modifications: none; protein mass: not specified; peptide tolerance: $\pm 1.2 \mathrm{kDa}$; mass values: $\mathrm{MH}+$; monoisotopic/average: monoisotopic; MS/MS: database: NCBInr; taxonomy: H. sapiens; enzyme: trypsin; missed cleavages allowed: 1; fixed modifications: none; quantitation: none; peptide tolerance: $\pm 1.2 \mathrm{kDa}$; MS/MS tolerance: $\pm 0.6 \mathrm{kDa}$; peptide charge: $1+$; monoisotopic/average: monoisotopic; precursor $\mathrm{m} / \mathrm{z}$ : not specified; instrument: MALDI-TOF-TOF. Variable modifications that were included in separate and combined submissions for both MS and MS/MS were acetyl (K), carbamidomethyl (C), deamidated (NQ), oxidation (M), phospho (ST), phospho (Y), sulfo (S), sulfo (T), and sulfo (Y). The general criteria used for assessment of protein identity were a minimum significant match of two MS/MS fragment scores (22).

\section{Western blot analysis (performed at Ohio University)}

Western blot analyses were performed to confirm the identity of haptoglobin, apolipoprotein A-1 (apoA-1), and transthyretin. For one-dimensional (D) gel electrophoresic immunoblots, $0.05 \mathrm{mg}$ of each sample was loaded onto a SDS-PAGE gel and transferred to PVDF membrane (Millipore, Billerica, MA, USA). For the 2D western blots, $0.3 \mathrm{mg}$ of each sample was subjected to 2DE and transferred to a PVDF membrane. Membranes were then blocked in 5\% nonfat dry milk and probed for $2 \mathrm{~h}$ with primary antibody. Antibodies against haptoglobin (mouse MAB anti-haptoglobin of human origin, 1:5000 dilution), apoA-1 (mouse MAB anti-apoA-1 of human origin, 1:500), and transthyretin (rabbit polyclonal antibody anti-prealbumin of human origin 1:500) were obtained from Santa Cruz Biotechnology (Santa Cruz, CA, USA). Protein bands and protein isoforms were identified with HRP-conjugated secondary antibody (1:5000 dilution) and Pierce ECL western blotting substrate (Thermo Scientific, Rockford, IL, USA). The resulting blots were scanned using a Pharos FX Plus Imaging System (Bio-Rad) and subjected to image analysis using Quantity One Quantification Program Software (Bio-Rad).

\section{Statistical analysis}

All protein spot intensities identified by 2DE were analyzed for normality (the Shapiro-Wilk test) and variance (homogeneity test for two dependent samples) (23). Protein spots displaying normal distributions and equal variances were compared between the two groups using a two-tailed paired $t$-test (corresponding $P$ values are reported; see significant spots $A, B$, and D). The nonparametric Wilcoxon signed-rank test was used to analyze the remaining data $(P$ values are reported; see spots C, E, F, and G). GH and IGF1 levels between the groups were also analyzed using a two-tailed paired $t$-test. All tests were performed using SPSS v. 14.0 (IBM Corporation, Somers, NY, USA). The levels of significance were set at $P<0.05$. 


\section{Results}

\section{GH and IGF1 values pre- and post-surgery}

Both nadir serum GH concentrations during the oral glucose load and total IGF1 levels decreased significantly $(P<0.05)$ after surgery (GH: $5.29 \pm 2.14 \mu \mathrm{g} / \mathrm{l}$ (pre) versus $0.62 \pm 0.21 \mu \mathrm{g} / \mathrm{l}$ (post); IGF1: $637 \pm 124 \mu \mathrm{g} / \mathrm{l}$ (pre) versus $242 \pm 41 \mu \mathrm{g} / \mathrm{l}$ (post)). Results are presented as mean and s.e.m. (Fig. 1A and B). The serum GH and IGF1 levels for each patient pre- and post-treatment are shown in Fig. $1 \mathrm{C}$ and D. The decline in IGF1 expressed as SDSs was also highly significant: $12.8 \pm 3.4$ (pre) versus $2.9 \pm 1.2$ (post). GH levels decreased markedly in seven patients following the surgery. In contrast, patient 2 (Fig. 1C) showed only a modest reduction in serum GH levels. Serum levels of IGF1 were normalized in five patients following the surgical treatment (Fig. 1D). Patient 1 presented a decrease in GH $(1.49 \mu \mathrm{g} / \mathrm{l}$ (pre) versus $0.53 \mu \mathrm{g} / \mathrm{l}$ (post)) but no reduction in IGF1 levels $(220 \mu \mathrm{g} / \mathrm{l}$ (pre) versus $211 \mu \mathrm{g} / \mathrm{l}$ (post)). Patients 6 and 7 showed a pronounced reduction in GH serum levels following the surgery, whereas the decrease in IGF1 failed to reach the normal range.

\section{Proteome changes post-surgery}

The proteomic profiles of all serum samples were evaluated in each subject at pre- and post-treatment time points. Protein profiles on all gels were reproducible and presented similar spot patterns (Fig. 2). A total of 150 protein spots were detected in each gel. Protein spot intensities were analyzed for significant changes
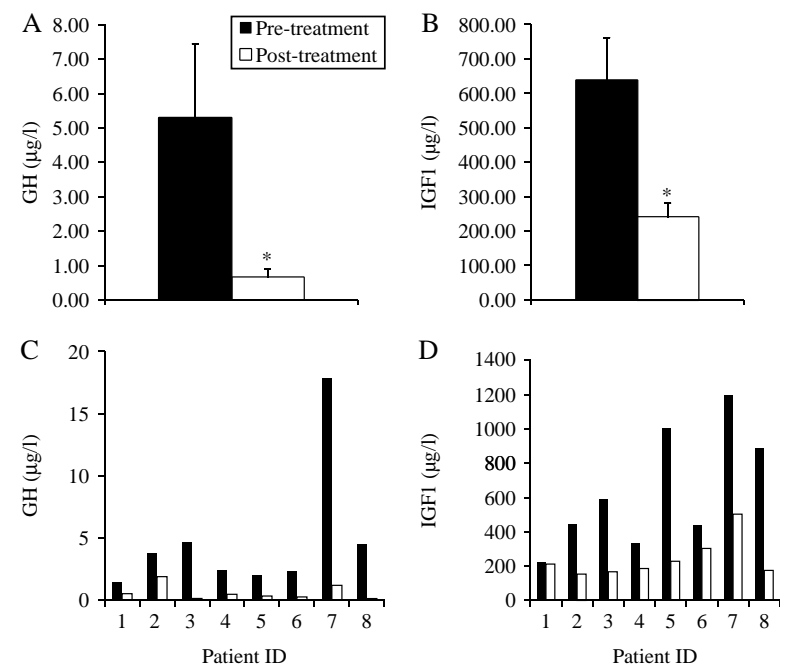

Figure 1 Mean \pm S.E.M. serum levels of nadir GH during the oral glucose load (A) and IGF1 (B) at pre-treatment (black) $(5.29 \pm 2.14 ; 0.62 \pm 0.21)$ and post-treatment (white) $(637 \pm 124$; $242 \pm 41)$. ${ }^{*} P<0.05$. The $P$ value is derived from two-tailed paired $t$-test. For statistics, please see text. GH (C) and IGF1 (D) serum levels in individual subjects (1-8) pre-treatment (black) and post-treatment (white). between pre- and post-surgical samples. Seven protein spots were significantly altered $(P<0.05)$; six decreased and one increased post-surgery (Fig. 2).

\section{Spot intensity changes observed in each individual subject pre- and post-surgery}

Figure 3 (I) shows the average intensity for protein spots A-G before and after the surgery. Protein spots A-F were significantly decreased $(P<0.05)$ following transsphenoidal surgery while protein spot $G$ increased $(P<0.05)$. Spot intensity values pre- and post-surgery showed similar expression patterns (decrease/increase) in all subjects (Fig. 3 (II)), suggesting positive associations between the expression of these specific proteins and the outcome of the surgical procedure.

\section{Protein identities}

The protein identities of spots A-G (Fig. 2) were determined using MS and MS/MS (Table 1). Among these proteins, two located at $\sim 15 \mathrm{kDa}$ (A and B) were identified as isoforms of transthyretin (Fig. 4 (I)). Both were downregulated (spot $\mathrm{A}, \mathrm{P}=0.02$ and spot $\mathrm{B}$, $P=0.01)$ (Fig. 4 (II)) after surgery. Protein spots $\mathrm{C}-\mathrm{F}$ also significantly decreased (Fig. 4 (II)) in the post-surgery serum samples. Spots $C(P=0.04)$ and D $(P=0.02)$ were identified as haptoglobin $\alpha 2(\sim 20 \mathrm{kDa})$ and $\beta$-hemoglobin $(\sim 12 \mathrm{kDa})$ respectively (Fig. 4 (I)). Spots E $(P=0.03)$ and $\mathrm{F}(P=0.03)$ located at $\sim 10 \mathrm{kDa}$ were identified as two isoforms of apoA-1 (Fig. 4 (I and II $))$. Protein spot $\mathrm{G}(\sim 35 \mathrm{kDa})(P=0.04)$ was identified as complement $\mathrm{C} 4 \mathrm{~B}$ precursor and was found to be significantly increased after the treatment (Fig. 4 (I and II)).

\section{Total haptoglobin levels and western blot analyses pre- and post-surgery}

Total haptoglobin serum levels were quantified (1.08 $\pm 0.24 \mathrm{~g} / \mathrm{l}$ (pre); $1.28 \pm 0.19 \mathrm{~g} / \mathrm{l}$ (post)). No statistically significant differences were found following transsphenoidal surgery (Fig. 5A). In agreement with these results, no differences in total haptoglobin levels were found by western blotting (Fig. 5B). In addition, no differences in apoA-1 and transthyretin were found by immunoblotting (Fig. 5B).

\section{$2 D$ western blotting to confirm identities of transthyretin, haptoglobin, and apoA-1}

Serum samples were subjected to 2D western blotting analysis to confirm the MS identifications of haptoglobin, apoA-1, and transthyretin. As shown in Fig. 6, western results are consistent with the MS results. Transthyretin isoforms were identified in a $\mathrm{pI}$ range of $\sim 5.5-7.2$ at two different MWs ( $\sim 15$ and $\sim 35 \mathrm{kDa}$ ) (Fig. 6 I and II (1)). 

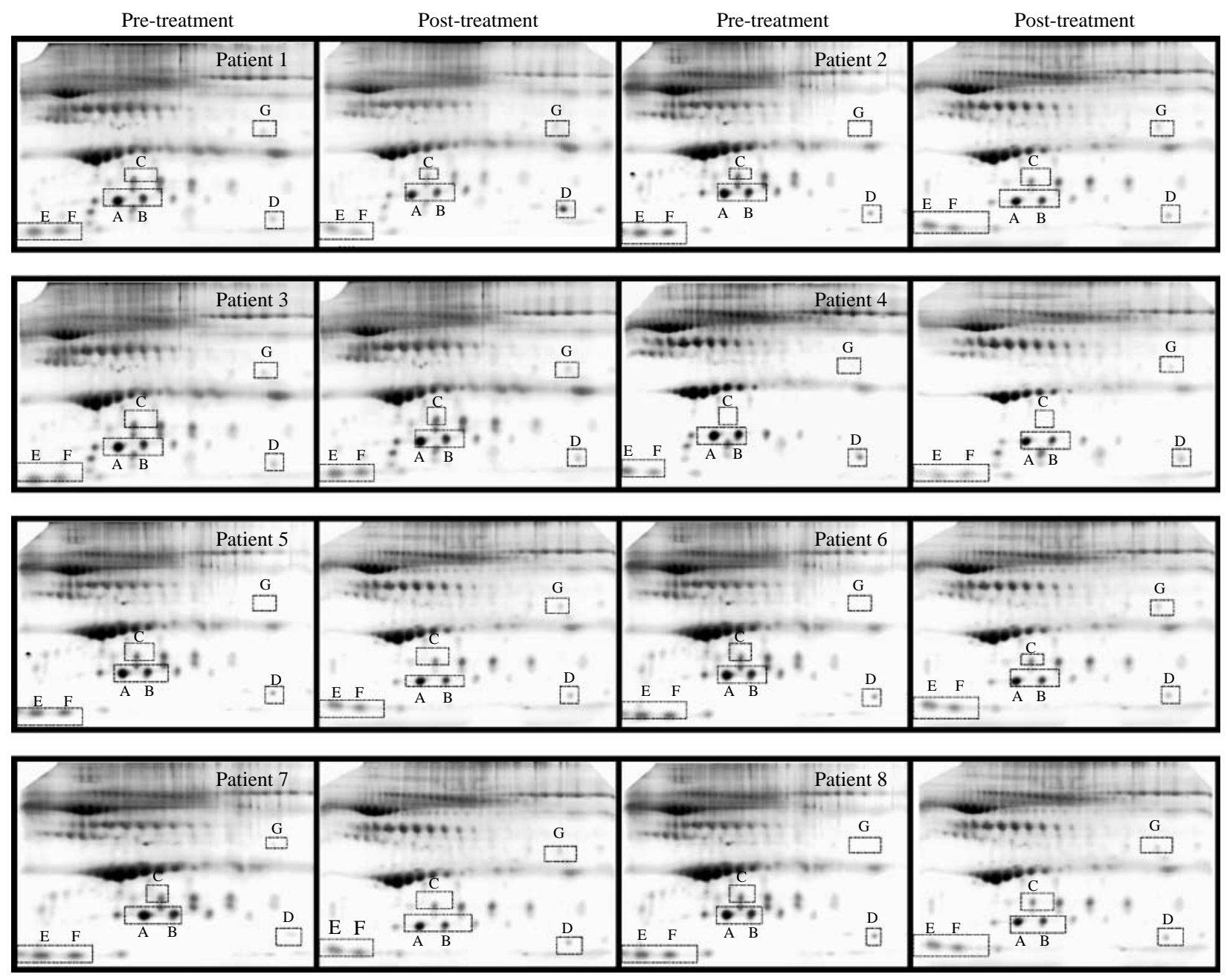

Figure 2 2DE gels showing the spot patterns. A total of 150 spots were analyzed. Images belong to patients 1-8 (see labels) and correspond to the pre- and post-surgery treatment. Seven spots displayed significant intensity changes post-treatment (A-G; dashed $(---)$ squares). These protein spots were used for mass spectrometry identification.

Two of these isoforms correspond to protein spots A (MW $\sim 15 \mathrm{kDa}, \mathrm{pI} \sim 6.0$ ) and $\mathrm{B}$ ( MW $\sim 15 \mathrm{kDa}$, pI 6.4) identified as transthyretin by MS. Haptoglobin $\alpha 2$ isoforms were identified at $\mathrm{MW}$ of $\sim 20 \mathrm{kDa}$ and a $\mathrm{pI}$ range of $\sim 5.7-7.5$ (Fig. 6 I and II (2)). One of the identified isoforms corresponds to spot C (MW $\sim 20 \mathrm{kDa}$, pI 6.2) identified as haptoglobin by MS. Finally, apoA-1 isoforms were located at a $\mathrm{MW}$ of $\sim 28 \mathrm{kDa}$ and $\mathrm{pI}$ ranging from $\sim 5.2$ to 7.8 (Fig. 6 I and II (3)). Protein spots $\mathrm{E}$ and $\mathrm{F}$ identified as apoA-1 by MS were not detected by western blotting techniques (Fig. 6 I (4)).

\section{Discussion}

This study focused on the analysis of the serum proteome of acromegalic patients before and after successful transsphenoidal adenomectomy. Although measurement of GH and IGF1 levels in acromegaly is the standard assay for assessment of disease activity, they are not perfect $(16,24-30)$. Additional factors such as age, gender, body composition, and nutritional status may interfere with the results $(31,32)$. As an example, in this study we found that the serum GH levels were significantly reduced in seven of the eight patients following surgery, whereas only five patients showed decrease in IGF1. These findings in this small number of patients supports the observation from larger studies that discordant values of $\mathrm{GH}$ and IGF1 often occur $(16,24-30)$. It is also noteworthy that, despite the observation that quality of life (QoL) is impaired in active acromegaly and improves with therapy, there is not complete agreement between traditional biomarkers and QoL in acromegaly (33). Therefore, additional biomarkers for acromegalic patients would be beneficial in order to provide rapid and reliable readouts of disease activity after surgery. 

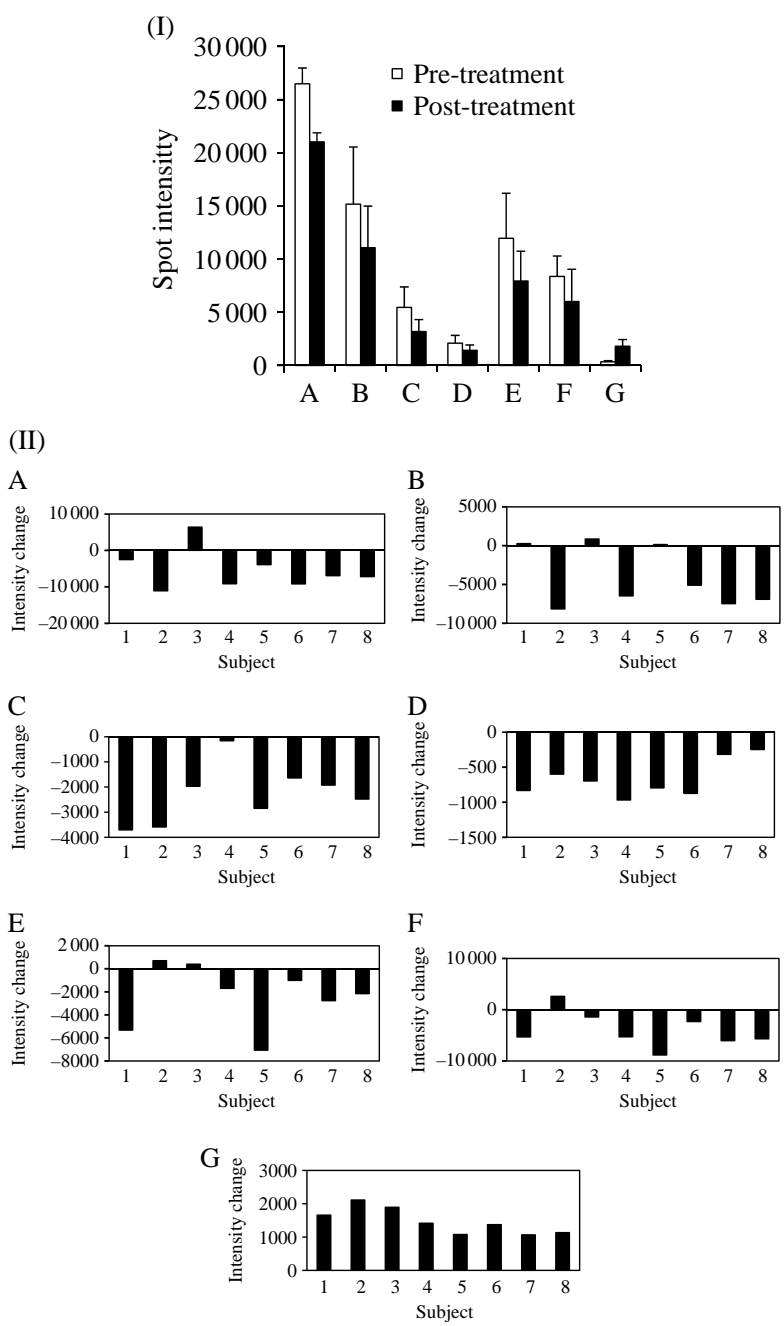

Figure 3 (I) Plots showing intensity values (mean \pm s.E.M.) before and after surgery for protein spots (A-G). (II) Spot intensity changes (intensity after treatment minus intensity before treatment) in individual subjects (1-8). Letters above each panel correspond to the spot shown in each graph.

Proteomics employing 2-D gel electrophoresis is a powerful technique that provides an atlas of proteins, that may show changes in protein levels and the presence of different protein isoforms or post-translational modifications (PTM) (34). Moreover, the use of fluorescent stains such as SYPRO Red, Ruby, and Orange (used in our study) improves the sensitivity of the technique, allowing the detection of individual protein spots at the nanogram level (4-8 ng) (21). We therefore have used a 2-D gel proteomic platform for the discovery of potential new serum biomarkers of acromegaly. We found seven proteins whose levels were significantly different $(P<0.05)$ after surgery in all patients. The protein spots were further analyzed by MS to reveal their identity.

Spots A and B were identified as isoforms of transthyretin. Serum transthyretin is a protein involved in retinol metabolism and in the transport of thyroid hormones in blood $(35,36)$. Normal serum values for transtyretin are between 15.7 and $29.6 \mathrm{mg} / \mathrm{dl}$ (37). Four isoforms of transthyretin (MW 13.8-35.39 kDa, pI 5.02-5.52) have been detected in human plasma by 2DE (SWISS-2 D PAGE; http://ca.expasy.org/swiss2 dpage/viewer). Recent reports have identified additional isoforms of this protein in mouse serum at different pIs and MWs to those previously recorded in the databases (38-40). One possible explanation for these results is the presence of PTM that may lead to shifts in $\mathrm{pI}$ and/or MW of a given protein (19). Thus, the differences in mass and/or charge observed in our samples may be due to PTMs, e.g. glycosylation or phosphorylations.

To further support our MS results, conventional 1D and 2D western blots were performed. No significant differences in total transthyretin levels were found by $1 \mathrm{D}$ immunoblots. A possible explanation is that although 1D western blotting is a sensitive technique (picogram levels of detection) it only provides information on the 'total' level of protein, and not on the differences in expression of particular isoforms of the target protein. On the other hand, 2D immunoblots showed the presence of several transthyretin isoforms at two different MWs of $\sim 15$ and $\sim 35 \mathrm{kDa}$ in a pI range of $\sim 5.5-7.2$. The $2 \mathrm{D}$ pattern of transthyretin isoforms was very similar following western blotting compared to 2DE gels. Two of these transthyretin isoforms corresponded to protein spots A and B (spot A MW $\sim 15 \mathrm{kDa}$, pI $\sim 6.0$; spot B MW $\sim 15$, pI $\sim 6.4$ ), confirming the identity assigned by MS.

Protein spots $\mathrm{C}$ and $\mathrm{D}$ were identified as haptoglobin $\alpha 2$ and $\beta$-hemoglobin respectively. Haptoglobin (HP) is an inflammation-inducible plasma protein, which in normal conditions is present in human serum in the range of $60-270 \mathrm{mg} / \mathrm{dl}$ (41). The HP molecule contains two different chains: $\beta$ (heavy, $40 \mathrm{kDa}$ ) and $\alpha$ (light $\alpha 1$, $8.9 \mathrm{kDa} ; \alpha 2,16 \mathrm{kDa})$. In the mature protein, the $\alpha$ and $\beta$ chains are connected by disulfide bridges $(\beta-\alpha-\alpha-\beta)$ (42). Two alleles (denoted 1 and 2) exist for the HP $\alpha$ gene in humans $(43,44)$. Therefore, three possible phenotypes results from these two alleles: HP 1-1, HP 2-2, and HP 2-1 $(43,44)$. The $\beta$ chain is present in all HP phenotypes, and it is always identical. Thus, HP variations are due to the presence of different $\alpha$ chains. Twenty-four isoforms (MW $\sim 11.86-44.46 \mathrm{kDa}$, pI 4.81-6.07) of HP have been identified by 2DE in human plasma. In addition, studies have shown that HP $\propto 2$ chain expression is increased in patients with neck and head cancer (45). In our results we show that the expression of one isoform of $\mathrm{HP} \alpha 2$ (MW $\sim 20 \mathrm{kDa}$, pI $\sim 6.2$ ) was markedly downregulated after surgery. Interestingly, no significant changes in the total concentration of HP were detected by a conventional ELISA assay; furthermore, the levels pre- and postsurgery were within normal ranges $(1.08 \pm 0.24 \mathrm{~g} / \mathrm{l}$ (pre); $1.28 \pm 0.19 \mathrm{~g} / \mathrm{l}$ (post)). Supporting these results, 
Table 1 Mass spectrometry of protein spots that changed significantly after treatment.

\begin{tabular}{|c|c|c|c|c|c|c|c|c|c|c|}
\hline Spot & $\begin{array}{c}\text { Gel } \\
(\mathrm{pl} / \mathrm{MW})\end{array}$ & Identity match & $\begin{array}{c}\text { Accession } \\
\text { no. }\end{array}$ & $\begin{array}{c}\% \text { Of } \\
\text { change }^{a}\end{array}$ & $\begin{array}{l}\text { MS } \\
\text { score }^{b}\end{array}$ & $\begin{array}{c}\text { Max } \\
\text { sequence } \\
\text { coverage } \\
(\%)\end{array}$ & $\begin{array}{l}\text { Matched } \\
\text { fragments }\end{array}$ & $\begin{array}{l}\text { MS/MS } \\
\text { score }^{c}\end{array}$ & $\begin{array}{c}\text { Max } \\
\text { sequence } \\
\text { coverage } \\
(\%)\end{array}$ & $\begin{array}{l}\text { Matched } \\
\text { fragments }\end{array}$ \\
\hline$A$ & $6.0 / 15$ & Transthyretin & P02766 & -20.60 & 172 & 95 & $13 / 40$ & 767 & 87 & 9/52 \\
\hline B & $6.4 / 15$ & Transthyretin & P02766 & -27.04 & 150 & 87 & $10 / 26$ & 314 & 67 & $6 / 35$ \\
\hline C & $6.2 / 20$ & Haptoglobin $\alpha 2$ & P00738 & -39.92 & 103 & 39 & $10 / 47$ & 394 & 22 & $6 / 59$ \\
\hline D & $7.8 / 12$ & $\beta$-Hemoglobin & Q14484 & -22.67 & 66 & 58 & $8 / 31$ & 64 & 6 & $6 / 31$ \\
\hline $\mathrm{E}$ & $5.0 / 10$ & ApoA-1 & P02647 & -33.65 & 158 & 48 & $14 / 38$ & 170 & 24 & $5 / 52$ \\
\hline $\mathrm{F}$ & $5.4 / 10$ & ApoA-1 & P02647 & -28.24 & 160 & 51 & $15 / 39$ & 292 & 26 & $6 / 53$ \\
\hline $\mathrm{G}$ & $7.5 / 35$ & $\begin{array}{l}\text { Complement C4B } \\
\text { precursor }^{\mathrm{d}}\end{array}$ & POCOL & 52.38 & & & & 77 & 1 & $2 / 27$ \\
\hline
\end{tabular}

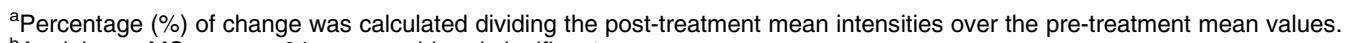

${ }^{\mathrm{b}} \mathrm{A}$ minimum MS score $>64$ was considered significant.

${ }^{\mathrm{C}} \mathrm{A}$ minimum of two significant MS/MS peptide fragments was considered to assign an ID for a spot.

${ }^{\mathrm{d}}$ Spot $\mathrm{G}$ was identified as complement C4B precursor based on the protein score obtained by ProteinPilot.

1D western blots showed no significant differences in total HP levels. On the other hand, several isoforms of $\mathrm{HP} \propto 2$ (MW $\sim 20 \mathrm{kDa}, \mathrm{pI} \sim 5.7-7.5$ ) were identified by 2D western blotting. One of the isoforms corresponded to protein spot $\mathrm{C}(\mathrm{MW} \sim 20 \mathrm{kDa}, \mathrm{pI} \sim 6.2)$.

Protein spot D was identified as $\beta$-hemoglobin. Hemoglobin is the principal component of the erythrocytes. Hemoglobin is a molecule composed of four globular protein subunits and four prosthetic heme groups. Its main function is to transport $\mathrm{O}_{2}$ from the lungs to the tissues (41). In normal physiological conditions, hemoglobin levels in serum range from 0.5 to $5.0 \mathrm{mg} / \mathrm{dl}$ (41). Previous studies have shown that total hemoglobin concentration has been positively correlated with IGF1 and IGFBP3 levels (46-48). However, these studies relate to heterotetrameric hemoglobin in erythrocytes (49) but not to the expression of free hemoglobin (released from the erythrocytes). Two isoforms of $\beta$-hemoglobin (MW $\sim 10.5 \mathrm{kDa}$, pI $\sim 6.88-7.05)$ are reported in the SWISS-2DPAGE database. Serum-free hemoglobin ( $\alpha$ and $\beta$ chains) has also been identified as a potential biomarker for ovarian and prostate cancer $(50,51)$. In addition, a recent report by Chung et al. (49) reported hemoglobin $\alpha$-chain as a biomarker of $\mathrm{GH}$ in serum. Moreover, serum proteomic studies by Sackmann-Sala et al. (19) identified an isoform of $\beta$-hemoglobin at a pI $\sim 8.0$ with MW of $\sim 12$ that changed due to increased GH/IGF1 action. In this study, we found that expression of one isoform of $\beta$-hemoglobin (MW $\sim 12 \mathrm{kDa}, \mathrm{pI}$ $\sim 7.8$ ) was decreased in the serum samples collected after the surgery. We were initially concerned with the result since the presence of hemoglobin might be due to red blood cell contamination of the serum. However, this is unlikely since all samples were handled consistently, and none of the samples revealed signs of hemolysis. Moreover, we observed that only one isoform of free hemoglobin was differentially expressed following the pituitary surgery. No changes in additional isoforms were detected. This may indicate that the differential expression of $\beta$-hemoglobin (spot D) is a specific effect associated with the surgical treatment and/or GH action and not the result of hemoglobin contamination from red blood cells.

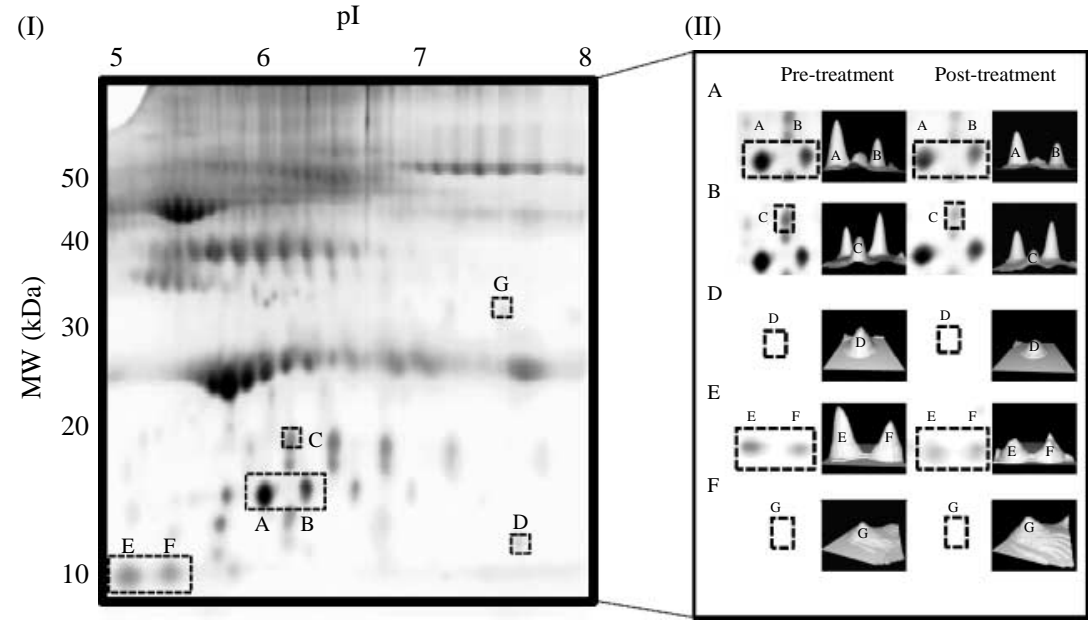

Figure 4 (I) Representative 2D serum gel. The locations of the seven protein spots displaying significant changes in intensity after transsphenoidal surgery are labeled A-G (--- dashed squares). (II) Representative $3 \mathrm{D}$ view of protein spots $\mathrm{A}-\mathrm{G}$ displaying intensities pre-treatment (left) and posttreatment (right). The images were generated using the 3D Viewer tool of PDQuest software version 8.0 , which converts the spot intensity data to topographical peaks and valleys. For each protein spot, left and right images belong to the same subject. 
A

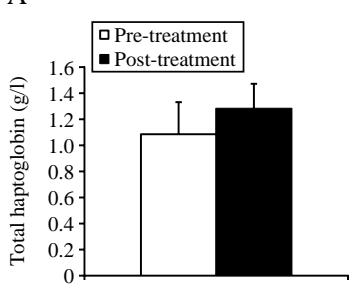

B

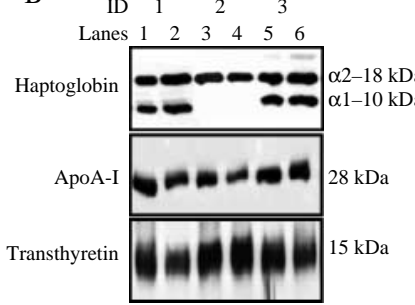

Figure 5 (A) Mean \pm S.E.M. serum levels of serum levels of haptoglobin pre-treatment (white) $(1.08 \mathrm{~g} / \mathrm{l} \pm 0.24)$ and post-treatment (black) $(1.28 \mathrm{~g} / \mathrm{l} \pm 0.19)$. (B) Western blots of haptoglobin, apoA-1, and transthyretin in serum samples. Representative images of three different patients (ID: 1, 2, and 3) pre-surgery (lanes 1,3 , and 5) and post-surgery (lanes 2, 4, and 6). Equal amounts of total protein were loaded $(0.05 \mathrm{mg})$ and separated by SDS-PAGE.

Spots E and F correspond to two isoforms of apoA-1, a major component of high-density lipoproteins (HDL) in human plasma and promoter of cholesterol efflux from the tissues to the liver (52). The apoA-1 concentration in normal human plasma ranges between 90 and $130 \mathrm{mg} / \mathrm{dl}$ (41). Nine isoforms of apoA-1 (MW 7.49-23.45 kDa, pI 4.79-7.27) have been reported. We have identified two isoforms of apoA-1 (MW $\sim 10 \mathrm{kDa}, \mathrm{pI} \sim 5.0$ and $\mathrm{MW} \sim 10 \mathrm{kDa}$, pI 5.4), which were significantly decreased postsurgery. Studies have shown that GH plays a role in the modulation of lipid metabolism in humans $(53,54)$. However, the effects of $\mathrm{GH}$ on cholesterol metabolism are still controversial. Some clinical studies on GH-deficient children showed no significant effects on the levels of total apoA-1 and HDL cholesterol after GH replacement treatment $(55,56)$, while others revealed decreases in apoA-1 serum levels $(56,57)$. In addition, normalization of $\mathrm{GH}$ serum levels in acromegalic patients after surgical and/or pharmacological treatment has been associated with increases in circulating apoA-1 (58). In this study, no significant difference in total apoA-1 levels was found by 1D western blots. As previously discussed, these results do not contradict previous observations, given that the changes in the levels of the two identified isoforms of apoA-1 occurred in response to the pituitary surgery, but not necessarily reflect the correlation between GH activity and apoA-1 levels. Interestingly, several isoforms of apoA-1 were identified by 2D western blots at a MW $\sim 28 \mathrm{kDa}$ and a pI range of 5.2-7.8; however, apoA-1 isoforms at lower MWs were not detected by this technique. A possible explanation is that post-translational modifications associated with the apoA-1 isoforms identified by MS may prevent the interactions between the antibody and its apoA-1 epitope. This is an important limitation of immuno-based techniques versus 2DE and MS.

Finally, spot $\mathrm{G}$ was identified as complement $\mathrm{C} 4 \mathrm{~B}$ precursor (MW $\sim 35 \mathrm{kDa}, \mathrm{pI} \sim 7.5$ ). To date, two isoforms (MW $\sim 31.73-31.94 \mathrm{kDa}, \mathrm{pI} \sim 6.41-6.54$ ) of

this protein have been identified by 2DE. C4B precursor undergoes proteolytic cleavages to produce the mature form of the protein, C4 (reference values in blood: $15-50 \mathrm{mg} / \mathrm{dl})(59,60)$. In its activated form, C4 is a subunit of the $\mathrm{C} 3$ and $\mathrm{C} 5$ convertases, the enzymatic complexes that activate $\mathrm{C} 3$ and $\mathrm{C} 5$ of the complement activation pathway $(61,62)$. Therefore, production of C4 in excess could lead to overactivation of the complement pathways and the inflammatory response (61). Studies in humans and animal models have demonstrated the effect of GH/IGF1 in the modulation of the immune response (63-65). A recent study showed that GH levels influence the expression of mannan-binding lectin (MBL), a plasma protein involved in the initiation of the complement cascade (66). The same study showed that MBL levels were reduced in acromegaly patients treated with octreotide or pegvisomant (66). Therefore, increased presence of C4B precursor in the serum of acromegalic patients following surgery may indicate reduced formation of activated $\mathrm{C} 4$, and perhaps decreased activation of the complement pathway. Studies are needed to evaluate the effects of surgical and/or pharmacological treatment in the immune response of acromegalic patients.

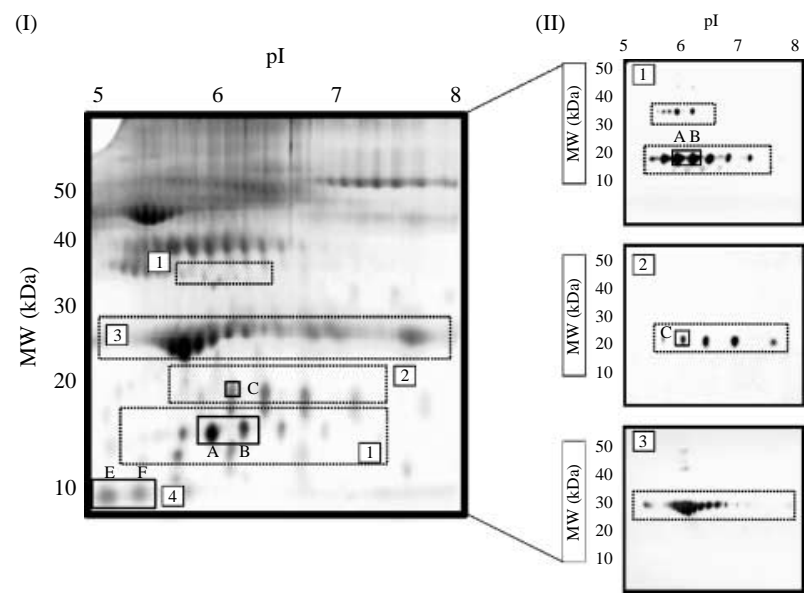

Figure 6 Isoforms observed by 2D western blots; (A) $150 \mu \mathrm{g}$ of total protein from serum was resolved in the first dimension in a linear $\mathrm{pH}$ range of 3-17 and in $15 \%$ acrylamide in the second dimension. (I) Representative 2D gel showing the location of protein spots (A-C, $E$, and F) (solid squares). Dashed (-- ) squares show the MW and pl range of the different protein isoforms identified by $2 \mathrm{D}$ western blots. Protein spots $A$ and $B$ were identified as transthyretin (1) (MW $\sim 15 \mathrm{kDa}, \mathrm{pl} \sim 6.0 ; \mathrm{MW} \sim 15 \mathrm{kDa}, \mathrm{pl} \sim 6.4$ ). Protein spot $\mathrm{C}$ was identified as haptoglobin $\alpha 2$ (2) (MW $\sim 20 \mathrm{kDa}, \mathrm{pl} \sim 6.2$ ). Isoforms of apoA-1 (3) were identified at a MW $\sim 28 \mathrm{kDa}$ and a pl range of $\sim 5.2-7.8$. Protein spots $\mathrm{E}$ and $\mathrm{F}(4)(\mathrm{MW} \sim 10 \mathrm{kDa}$, pl $\sim 5.0$; $\mathrm{MW}$ $\sim 10 \mathrm{kDa}, \mathrm{pl} \sim 5.4$ ) identified by MS as apoA-1 (see Table 1) were not detected by western blotting. Molecular weight markers are indicated to the left of the panels and pl markers are shown on the top. (II) Representative 2D western blots revealing (1) transthyretin, (2) haptoglobin $\alpha 2$ and (3) apoA-1. The identified protein isoforms $(---$ dashed squares) and the localization of protein spots $A-C$ (solid squares) are shown. 
In summary, the results presented here reveal potential biomarkers of disease activity after treatment by surgery. Further studies using serum samples from acromegalic patients undergoing different therapies (e.g. somatostatin analogs or $\mathrm{GH}$ receptor antagonists) as well as from surgical patients who did not achieve GH/IGF1 normalization would be beneficial. In addition, studies to investigate whether variations in the protein levels of the identified isoforms are directly associated to $\mathrm{GH}$ activity or other factors (e.g. cardiovascular and metabolic changes associated to decreased GH) are needed to further support our results.

\section{Declaration of interest}

The authors declare that there is no conflict of interest that could be perceived as prejudicing the impartiality of the research reported.

\section{Funding}

This work was supported by a grant from the World Anti-Doping Agency (WADA) and by the State of Ohio's Eminent Scholars Program that includes a gift by Milton and Lawrence Goll. J J Kopchick is supported by the following grants: NIH R15DK075436; NIH R01AG019899; and 1P01AG031736-01A1.

\section{Acknowledgements}

We acknowledge Juan Ding, $\mathrm{PhD}$ for her helpful discussions regarding the mass spectrometry data.

\section{References}

1 Kopchick JJ, Parkinson C, Stevens EC \& Trainer PJ. Growth hormone receptor antagonists: discovery, development, and use in patients with acromegaly. Endocrine Reviews 200223 623-646. (doi:10.1210/er.2001-0022)

2 Moller N \& Jorgensen JO. Effects of growth hormone on glucose, lipid, and protein metabolism in human subjects. Endocrine Reviews 200930 152-177. (doi:10.1210/er.2008-0027)

3 Berryman DE, List EO, Palmer AJ, Chung MY, Wright-Piekarski J, Lubbers E, O'Connor P, Okada S \& Kopchick JJ. Two-year body composition analyses of long-lived GHR null mice. Journals of Gerontology. Series A, Biological Sciences and Medical Sciences 2009 65 31-40. (doi:10.1093/gerona/glp175)

4 List EO, Palmer AJ, Berryman DE, Bower B, Kelder B \& Kopchick JJ. Growth hormone improves body composition, fasting blood glucose, glucose tolerance and liver triacylglycerol in a mouse model of diet-induced obesity and type 2 diabetes. Diabetologia 200952 1647-1655. (doi:10.1007/s00125-009-1402-z)

5 Dostalova S, Sonka K, Smahel Z, Weiss V \& Marek J. Cephalometric assessment of cranial abnormalities in patients with acromegaly. Journal of Cranio-Maxillo-Facial Surgery 200331 80-87. (doi:10. 1016/S1010-5182(02)00182-8)

6 Ayuk J \& Sheppard MC. Does acromegaly enhance mortality? Reviews in Endocrine \& Metabolic Disorders 20089 33-39. (doi:10. 1007/s11154-007-9067-8)

7 Loeper S \& Ezzat S. Acromegaly: re-thinking the cancer risk. Reviews in Endocrine \& Metabolic Disorders 2008 9 41-58. (doi:10. 1007/s11154-007-9063-z)

8 Holdaway IM, Bolland MJ \& Gamble GD. A meta-analysis of the effect of lowering serum levels of GH and IGF-I on mortality in acromegaly. European Journal of Endocrinology 2008159 89-95. (doi:10.1530/EJE-08-0267)
9 Ebner FH, Kuerschner V, Dietz K, Bueltmann E, Naegele T \& Honegger J. Reduced intercarotid artery distance in acromegaly: pathophysiologic considerations and implications for transsphenoidal surgery. Surgical Neurology 2009 72 456-460 (discussion 460). (doi:10.1016/j.surneu.2009.07.006)

10 Gondim JA, Ferraz T, Mota I, Studart D, Almeida JP, Gomes E \& Schops M. Outcome of surgical intrasellar growth hormone tumor performed by a pituitary specialist surgeon in a developing country. Surgical Neurology 2009 72 15-19 (discussion 19). (doi:10.1016/j.surneu.2008.02.012)

11 Melmed S. Acromegaly pathogenesis and treatment. Journal of Clinical Investigation $2009 \mathbf{1 1 9} \quad 3189-3202$. (doi:10.1172/ JCI39375)

12 Petrossians P, Borges-Martins L, Espinoza C, Daly A, Betea D, Valdes-Socin H, Stevenaert A, Chanson P \& Beckers A. Gross total resection or debulking of pituitary adenomas improves hormonal control of acromegaly by somatostatin analogs. European Journal of Endocrinology 2005152 61-66. (doi:10.1530/eje.1.01824)

13 Shimon I, Cohen ZR, Ram Z \& Hadani M. Transsphenoidal surgery for acromegaly: endocrinological follow-up of 98 patients. Neurosurgery 200148 1239-1243 (discussion 1244-1245). (doi:10.1097/00006123-200106000-00008)

14 Damjanovic SS, Neskovic AN, Petakov MS, Popovic V, Macut D, Vukojevic P \& Joksimovic MM. Clinical indicators of biochemical remission in acromegaly: does incomplete disease control always mean therapeutic failure? Clinical Endocrinology 200562 410-417. (doi:10.1111/j.1365-2265.2005.02233.x)

15 Giustina A, Barkan A, Casanueva FF, Cavagnini F, Frohman L, Ho K, Veldhuis J, Wass J, Von Werder K \& Melmed S. Criteria for cure of acromegaly: a consensus statement. Journal of Clinical Endocrinology and Metabolism 200085 526-529. (doi:10.1210/ jc.85.2.526)

16 Carmichael JD, Bonert VS, Mirocha JM \& Melmed S. The utility of oral glucose tolerance testing for diagnosis and assessment of treatment outcomes in 166 patients with acromegaly. Journal of Clinical Endocrinology and Metabolism $2009 \mathbf{9 4}$ 523-527. (doi:10.1210/jc.2008-1371)

17 Jorgensen JO, Feldt-Rasmussen U, Frystyk J, Chen JW, Kristensen LO, Hagen C \& Orskov H. Cotreatment of acromegaly with a somatostatin analog and a growth hormone receptor antagonist. Journal of Clinical Endocrinology and Metabolism 2005 90 5627-5631. (doi:10.1210/jc.2005-0531)

18 List EO, Berryman DE, Palmer AJ, Qiu L, Sankaran S, Kohn DT, Kelder B, Okada S \& Kopchick JJ. Analysis of mouse skin reveals proteins that are altered in a diet-induced diabetic state: a new method for detection of type 2 diabetes. Proteomics 20077 1140-1149. (doi:10.1002/pmic.200600641)

19 Sackmann-Sala L, Ding J, Frohman LA \& Kopchick JJ. Activation of the GH/IGF-1 axis by CJC-1295, a long-acting GHRH analog, results in serum protein profile changes in normal adult subjects. Growth Hormone and IGF Research 200919 471-477. (doi:10. 1016/j.ghir.2009.03.001)

20 Qiu L, List EO \& Kopchick JJ. Differentially expressed proteins in the pancreas of diet-induced diabetic mice. Molecular and Cellular Proteomics 20054 1311-1318. (doi:10.1074/mcp.M500016MCP200)

21 Ding J, List EO, Okada S \& Kopchick JJ. Perspective: proteomic approach to detect biomarkers of human growth hormone. Growth Hormone and IGF Research 200919 399-407. (doi:10. 1016/j.ghir.2009.04.018)

22 Salmi J, Moulder R, Filen JJ, Nevalainen OS, Nyman TA, Lahesmaa R \& Aittokallio T. Quality classification of tandem mass spectrometry data. Bioinformatics 200622 400-406. (doi:10.1093/bioinformatics/bti829)

23 Sheskin D. Handbook of Parametric and Nonparametric Statistical Procedures Boca Raton, FL: CRC Press, 1997.

24 Freda PU, Landman RE, Sundeen RE \& Post KD. Gender and age in the biochemical assessment of cure of acromegaly. Pituitary 2001 4 163-171. (doi:10.1023/A:1015314906972) 
25 Freda PU. How effective are current therapies for acromegaly? Growth Hormone \& IGF Research 200313 (Supplement A) S144-S151. (doi:10.1016/S1096-6374(03)00072-8)

26 Freda PU, Nuruzzaman AT, Reyes CM, Sundeen RE \& Post KD. Significance of "abnormal" nadir growth hormone levels after oral glucose in postoperative patients with acromegaly in remission with normal insulin-like growth factor-I levels. Journal of Clinical Endocrinology and Metabolism 200489 495-500. (doi:10.1210/ jc.2003-031316)

27 Parkinson C, Renehan AG, Ryder WD, O'Dwyer ST, Shalet SM \& Trainer PJ. Gender and age influence the relationship between serum GH and IGF-I in patients with acromegaly. Clinical Endocrinology $2002 \quad 57 \quad 59-64 . \quad$ (doi:10.1046/j.1365-2265. 2002.01560.x)

28 Peacey SR \& Shalet SM. Insulin-like growth factor 1 measurement in diagnosis and management of acromegaly. Annals of Clinical Biochemistry 200138 297-303. (doi:10.1258/00045630119 00678)

29 Biermasz NR, van Dulken H \& Roelfsema F. Ten-year follow-up results of transsphenoidal microsurgery in acromegaly. Journal of Clinical Endocrinology and Metabolism $2000 \quad 85$ 4596-4602. (doi:10.1210/jc.85.12.4596)

30 Kreutzer J, Vance ML, Lopes MB \& Laws ER Jr. Surgical management of $\mathrm{GH}$-secreting pituitary adenomas: an outcome study using modern remission criteria. Journal of Clinical Endocrinology and Metabolism 200186 4072-4077. (doi:10. $1210 /$ jc. 86.9.4072)

31 Pokrajac A, Wark G, Ellis AR, Wear J, Wieringa GE \& Trainer PJ. Variation in GH and IGF-I assays limits the applicability of international consensus criteria to local practice. Clinical Endocrinology $2007 \quad 67 \quad 65-70$. (doi:10.1111/j.1365-2265.2007. 02836.x)

32 Arafat AM, Mohlig M, Weickert MO, Perschel FH, Purschwitz J, Spranger J, Strasburger CJ, Schofl C \& Pfeiffer AF. Growth hormone response during oral glucose tolerance test: the impact of assay method on the estimation of reference values in patients with acromegaly and in healthy controls, and the role of gender, age, and body mass index. Journal of Clinical Endocrinology and Metabolism 200893 1254-1262. (doi:10.1210/jc.2007-2084)

33 Webb SM. Quality of life in acromegaly. Neuroendocrinology 2006 83 224-229. (doi:10.1159/000095532)

34 Hellgren G, Andersson B, Nierop AF, Dahlgren J, Hochberg Z \& Albertsson-Wikland K. A proteomic approach identified growth hormone-dependent nutrition markers in children with idiopathic short stature. Proteome Science 20086 35. (doi:10.1186/14775956-6-35)

35 Power DM, Elias NP, Richardson SJ, Mendes J, Soares CM \& Santos CR. Evolution of the thyroid hormone-binding protein, transthyretin. General and Comparative Endocrinology 2000119 241-255. (doi:10.1006/gcen.2000.7520)

36 Fung ET, Yip TT, Lomas L, Wang Z, Yip C, Meng XY, Lin S, Zhang F, Zhang Z, Chan DW \& Weinberger SR. Classification of cancer types by measuring variants of host response proteins using SELDI serum assays. International Journal of Cancer 2005115 783-789. (doi:10.1002/ijc.20928)

37 Liu L, Wang J, Liu B, Dai S, Wang X, Chen J, Huang L, Xiao X \& He D. Serum levels of variants of transthyretin down-regulation in cholangiocarcinoma. Journal of Cellular Biochemistry 2008104 745-755. (doi:10.1002/jcb.21661)

38 Hoogland C, Mostaguir K, Sanchez JC, Hochstrasser DF \& Appel RD. SWISS-2DPAGE, ten years later. Proteomics 20044 2352-2356. (doi:10.1002/pmic.200300830)

39 Okada S, List EO, Sankaran S \& Kopchick JJ. Plasma protein biomarkers correlated with the development of diet-induced type 2 diabetes in mice. Clinical Proteomics 20106 6-17. (doi:10.1007/ s12014-009-9040-5)

40 Ding J \& Kopchick JJ. Plasma biomarkers of mouse aging. Age, 2010. (doi:10.1007/s11357-010-9179-z)

41 Henry JB. Clinical Diagnosis and Management by Laboratory Methods Philadelphia: W.B. Saunders, 2001.
42 Koch W, Latz W, Eichinger M, Roguin A, Levy AP, Schomig A \& Kastrati A. Genotyping of the common haptoglobin Hp 1/2 polymorphism based on PCR. Clinical Chemistry 200248 1377-1382.

43 Cheng TM, Pan JP, Lai ST, Kao LP, Lin HH \& Mao SJ. Immunochemical property of human haptoglobin phenotypes: determination of plasma haptoglobin using type-matched standards. Clinical Biochemistry 200740 1045-1056. (doi:10. 1016/j.clinbiochem.2007.04.018)

44 Melamed-Frank M, Lache O, Enav BI, Szafranek T, Levy NS, Ricklis RM \& Levy AP. Structure-function analysis of the antioxidant properties of haptoglobin. Blood 200198 3693-3698. (doi:10.1182/blood.V98.13.3693)

45 Chen CB, Su YC, Huang TT, Ho HC, Chang YT, Tung YT \& Lee WC. Differentially expressed serum haptoglobin alpha chain isoforms with potential application for diagnosis of head and neck cancer. Clinica Chimica Acta 2008398 48-52. (doi:10.1016/j.cca.2008. 08.001)

46 Nilsson-Ehle H, Bengtsson BA, Lindstedt G \& Mellstrom D. Insulin-like growth factor-1 is a predictor of blood haemoglobin concentration in 70-yr-old subjects. European Journal of Haematology $2005 \mathbf{7 4}$ 111-116. (doi:10.1111/j.1600-0609. 2004.00374.x)

47 Sohmiya M \& Kato Y. Human growth hormone and insulin-like growth factor-I inhibit erythropoietin secretion from the kidneys of adult rats. Journal of Endocrinology 2005184 199-207. (doi:10. 1677 /joe.1.05899)

48 Vihervuori E, Virtanen M, Koistinen H, Koistinen R, Seppala M \& Siimes MA. Hemoglobin level is linked to growth hormonedependent proteins in short children. Blood 199687 2075-2081.

49 Chung L, Clifford D, Buckley M \& Baxter RC. Novel biomarkers of human growth hormone action from serum proteomic profiling using protein chip mass spectrometry. Journal of Clinical Endocrinology and Metabolism 200691 671-677. (doi:10.1210/ jc.2005-1137)

50 Vollmer RT, Kantoff PW, Dawson NA \& Vogelzang NJ. Importance of serum hemoglobin in hormone refractory prostate cancer. Clinical Cancer Research 20028 1049-1053.

51 Kozak KR, Amneus MW, Pusey SM, Su F, Luong MN, Luong SA, Reddy ST \& Farias-Eisner R. Identification of biomarkers for ovarian cancer using strong anion-exchange ProteinChips: potential use in diagnosis and prognosis. PNAS 2003100 12343-12348. (doi:10.1073/pnas.2033602100)

52 Shoulders CC, Kornblihtt AR, Munro BS \& Baralle FE. Gene structure of human apolipoprotein A1. Nucleic Acids Research 198311 2827-2837. (doi:10.1093/nar/11.9.2827)

53 Yildiz M, Arslanoglu I, Yildiz N, Nartop F, Isik K \& Isguven P. Effects of growth hormone replacement therapy on lipids, lipoproteins and apolipoproteins: is the increased apolipoprotein A-1/B ratio the only benefit? Pediatrics International $2000 \quad 42$ 151-154. (doi:10.1046/j.1442-200x.2000.01193.x)

54 Lanes R, Soros A, Gunczler P, Paoli M, Carrillo E, Villaroel O \& Palacios A. Growth hormone deficiency, low levels of adiponectin, and unfavorable plasma lipid and lipoproteins. Journal of Pediatrics 2006149 324-329. (doi:10.1016/j.jpeds.2006.05.010)

55 Schaefer GB, Greger NG, Fesmire JD, Blackett PR, Wilson DP \& Frindik JP. Lipids and apolipoproteins in growth hormone-deficient children during treatment. Metabolism 199443 1457-1461. (doi:10.1016/0026-0495(94)90001-9)

56 Blackett PR, Weech PK, McConathy WJ \& Fesmire JD. Growth hormone in the regulation of hyperlipidemia. Metabolism 198231 117-120. (doi:10.1016/0026-0495(82)90121-4)

57 Parkinson C, Drake WM, Wieringa G, Yates AP, Besser GM \& Trainer PJ. Serum lipoprotein changes following IGF-I normalization using a growth hormone receptor antagonist in acromegaly. Clinical Endocrinology 200256 303-311. (doi:10.1046/j. 1365-2265.2002.01460.x)

58 Oscarsson J, Wiklund O, Jakobsson KE, Petruson B \& Bengtsson BA. Serum lipoproteins in acromegaly before and 
6-15 months after transsphenoidal adenomectomy. Clinical Endocrinology 199441 603-608. (doi:10.1111/j.1365-2265. 1994.tb01825.x)

59 Chan AC \& Atkinson JP. Functional studies on the secreted form of human $\mathrm{C} 4$ (C4s), two incompletely processed two-subunit $\mathrm{C} 4$ molecules (beta - alpha + gamma and beta + alpha - gamma), and pro-C4. Journal of Immunology 1984132 1967-1971.

60 Banyai A, Varga L, Barta A, Gopcsa L \& Paloczi K. Monitoring the level of complement components during autologous blood stem cell transplantation in patients with malignant lymphomas. Cancer Immunology, Immunotherapy 200453 835-839. (doi:10.1007/ s00262-004-0519-7)

61 Blanchong CA, Chung EK, Rupert KL, Yang Y, Yang Z, Zhou B, Moulds JM \& Yu CY. Genetic, structural and functional diversities of human complement components $\mathrm{C} 4 \mathrm{~A}$ and $\mathrm{C} 4 \mathrm{~B}$ and their mouse homologues, Slp and C4. International Immunopharmacology 2001 1 365-392. (doi:10.1016/S1567-5769(01)00019-4)

62 Belt KT, Carroll MC \& Porter RR. The structural basis of the multiple forms of human complement component C4. Cell 1984 36 907-914. (doi:10.1016/0092-8674(84)90040-0)

63 Liao W, Rudling M \& Angelin B. Growth hormone potentiates the in vivo biological activities of endotoxin in the rat. European
Journal of Clinical Investigation 199626 254-258. (doi:10.1046/j. 1365-2362.1996.140268.x)

64 Liao W, Rudling M \& Angelin B. Contrasting effects of growth hormone and insulin-like growth factor I on the biological activities of endotoxin in the rat. Endocrinology $1997 \mathbf{1 3 8}$ 289-295. (doi:10.1210/en.138.1.289)

65 Takala J, Ruokonen E, Webster NR, Nielsen MS, Zandstra DF, Vundelinckx G \& Hinds CJ. Increased mortality associated with growth hormone treatment in critically ill adults. New England Journal of Medicine 1999341 785-792. (doi:10.1056/NEJM1999 09093411102)

66 Hansen TK, Thiel S, Dall R, Rosenfalck AM, Trainer P, Flyvbjerg A, Jorgensen JO \& Christiansen JS. GH strongly affects serum concentrations of mannan-binding lectin: evidence for a new IGF-I independent immunomodulatory effect of GH. Journal of Clinical Endocrinology and Metabolism $2001 \quad 86$ 5383-5388. (doi:10.1210/jc.86.11.5383)

Received 14 October 2010

Accepted 8 November 2010 